\title{
$\mathrm{Cu}-\mathrm{Sn}$ 청동기의 미세조직 변화 양상이 색도 변화에 미치는 영향
}

\author{
이재성 | 박장식*1 \\ 국립나주문화재연구소, *홍익대학교 금속공학과
}

\section{Effect of Changes on Color Characteristics by Microstructural Transformations of Cu-Sn Bronzes}

\author{
Jae-Sung Lee ${ }^{1} \mid$ Jang-Sik Park ${ }^{* 1}$ \\ Naju National Research Institute of Cultural Heritage, Naju, 520-230, Korea \\ *Department of Metallurgical Engineering, Hongik University, Sejong, 339-701, Korea \\ ${ }^{1}$ Corresponding Author: jskpark@hongik.ac.kr, +82-44-860-2562
}

\begin{abstract}
초 록 구리에 다양한 비율의 주석을 혼합하여 청동합금을 제작하고 합금 비율에 따른 색도 변화를 분석하였다. 색도를 미세조직의 변화와 함께 분석한 결과, $\mathrm{Cu}-\mathrm{Sn}$ 청동은 주석함량이 높아질수록 적 · 황색도를 나타내는 $\mathrm{a}$ *와 $b$ *값은 감소하 며 전체적인 백색도가 크게 증가하였다. 하지만 백색도와 밀접한 $\mathrm{L}^{*}$ 값이 감소하는 특이한 현상을 보였다. $\mathrm{Cu}-\mathrm{Sn}$ 청동의 미세조직 내에서 존재하는 $a$ 상의 비율이 증가될수록 적 · 황색도가 높아졌고, $\delta$ 상의 비율이 증가할수록 $\mathrm{a*}$ *와 $\mathrm{b}$ *값이 낮아졌다. 한편 동일한 성분 조성을 가진 $\mathrm{Cu}-22 \% \mathrm{Sn}$ 청동을 다양한 열처리 조건으로 상변화를 일으킬 경우 주조 조직인 $a+\delta$ 상과 담금질 조직인 $a+\gamma$ 상, $\alpha+\beta$ 상에서 미세한 색도변화가 일어났다. 이는 동일한 조성의 합금도 다른 분율을 가진 미세조직을 생성시킴에 따라 색상 변화가 생길 수 있음을 보여준다. $\mathrm{Cu}-\mathrm{Sn}$ 청동을 담금질할 경우, 합금 내에서의 미세조 직 변화에 따른 적·황색도는 $\alpha$ 상, $\beta$ 상, $\gamma$ 상, $\delta$ 상의 순으로 감소하였다.
\end{abstract}

중심어: $\mathrm{Cu}-\mathrm{Sn}$ 청동기, 색도, 미세조직, 열처리

ABSTRACT Color characteristics of the $\mathrm{Cu}$-Sn alloys (bronze) in as-cast conditions were determined by reference to the $L^{*}, a^{*}, b^{*}$ color space. Results show that the values of $a^{*}$ and $b^{*}$ decrease with the increase in Sn levels, indicating that the colors of bronze alloys are increasingly away from red and yellow with the increase in the fraction of the $\delta$ phase while the opposite is true with the a phase. It has also been found in similar experiments with the $\mathrm{Cu}-22 \% \mathrm{Sn}$ alloys that heat treatments in varying conditions produce subtle differences in their color characteristics as observed in the $L^{*}, a^{*}, b^{*}$ color space, due likely to the formation of various phases in different fractions.

Key Words: Cu-Sn bronze, Color characteristics, Microstructure, Heat treatment

\section{1. 서 론}

청동 합금은 수천년 전부터 구리 소재의 기계적 성질을
개선하기 위해 다른 금속을 혼합해 사용해 왔다. 이와 같은 합금의 개발은 인류의 발전으로 이어졌으며, 고대에 만들 어진 구리와 주석의 합금인 청동은 지금까지도 인류의 일 
상생활에 중요한 금속 소재로 사용되고 있다.

청동은 주성분으로 구리와 주석을 혼합해 만들기 때문 에 포함된 금속의 고유 색상에 따라 다양한 색도 변화가 생 기며, 그 함량에 따라 금속학적 특성도 달라진다. 그러므로 각 금속이 가지는 고유의 특성과 색상을 이해한다면 합금 의 색변화를 통해 그 합금이 가지는 금속학적 특성을 유추 할 수 있다. 주석 함량에 따른 청동기의 특성과 색상을 고 려한 용도에 적합한 청동 합금의 설계는 중국 옛 문헌인 『주례고공기』에 잘 기록되어 있다. 또한 출토되는 청동유 물이 용도에 따라 구리와 주석의 합금비율이 다르다는 과 학적인 분석결과는 청동기를 생산하던 초기부터 기계적 특성만큼 색상도 매우 중요했다는 것을 알 수 있다. 이처럼 합금 비율에 따른 청동기의 색상 변화는 청동거울, 동탁 등 의 재현실험을 통해 주석함량에 따라 변화되는 색상과 기 계적 특성을 연구하였다.(Hirao, 2001; Chung et al., 2008). 하지만 어떠한 미세조직이 색상 변화에 큰 형향을 미치는 지는 심도 있게 연구되지 않았다.

우리나라의 전통 청동기인 방짜유기처럼 제작 단계별 로 미세조직의 다양한 변화를 보이는 경우, 동일한 함량의 청동 합금일지라도 열처리 조건에 따라 상이한 미세조직 이 생성되기 때문에 육안으로는 관찰되지 않는 색도에 변 화가 생겼을 가능성이 매우 크다. 그러나 동일한 합금 비율 에서의 미세한 색도 변화는 육안으로 관찰이 어렵고, 인간 의 눈으로 관찰하는 색은 매우 주관적이어서 광원이나 배경 의 차이에 의해서 같은 색이라도 다르게 보인다(Gyeonggi provincial museum, 2008). 또한 색상을 표현하는 것도 감 각적으로 이루어지기 때문에 색변화에 따른 금속의 특성 변화를 이해하는데 한계가 있다. 이러한 한계를 극복하기 위해서는 국제규격을 가진 색도 측정용 광학기기를 이용 한 객관적인 색도 변화의 자료 확보가 매우 중요하다.

본 연구에서는 구리에 다양한 비율의 주석을 혼합하여 청동 합금을 제작하고 합금 비율에 따른 색도 변화를 분석 하였다. 또한 상변화 조성에 맞춰 담금질하고 여기서 나타 나는 미세조직의 변화와 색도 변화를 비교 분석함으로써 합금의 조성을 결정함에 색도가 미친 영향을 추정해 보았다.

\section{2. 실험 및 분석방법}

동일한 함량의 청동합금에서 미세조직의 변화에 따른 색도 변화를 분석하기 위해 $\mathrm{Cu}-\mathrm{Sn}$ 합금을 열처리하였다. 실험을 위해 순구리에 주석을 $10,15,22,25,27,30 \%$ 의 무게비로 6 종의 $\mathrm{Cu}-\mathrm{Sn}$ 합금을 제작하였다. 시험편 제작방
법은 구리와 주석을 각각의 무게비로 합금한 용융액을 직 경(내경) $15 \mathrm{~mm}$ 크기의 원통형 세라믹튜브에서 응고시킨 뒤, 세라믹튜브에서 꺼내어 합금 종류별로 각각 3 개씩 절 단하였다. 동일한 함량의 $\mathrm{Cu}-\mathrm{Sn}$ 합금의 미세조직 변화를 관찰하기 위해 3 개의 시험편 중 미세조직 변화 전 상태를 보여주는 기준 시험편(as-cast) 1 개를 제외한 나머지 2개를 각각 다른 온도 조건에서 담금질하였다. 담금질 방법은 각 각의 시험편을 $550^{\circ} \mathrm{C}$ 와 $700^{\circ} \mathrm{C}$ 의 고온에서 1 시간 동안 유 지한 후 찬물에 급냉시켰다. 본 실험의 담금질 온도 조건인 $550^{\circ} \mathrm{C}$ 와 $700^{\circ} \mathrm{C}$ 는 주석함량 $30 \%$ 이하의 $\mathrm{Cu}-\mathrm{Sn}$ 합금 6 종 을 동일한 온도 조건에서 다양한 변화를 관찰할 수 있는 가 장 적합한 온도 구간으로 판단되어 이 온도에서 담금질하 였다. 또한 $550^{\circ} \mathrm{C}$ 와 $700^{\circ} \mathrm{C}$ 는 우리나라의 전통 청동기 제 작기술로 만들어진 유기(鍮器)에서 많이 관찰되는 $\gamma$ 상이 나 $\beta(\mathrm{M})$ 상이 생성되는 온도조건이기도 하다.

청동합금의 색도를 측정하는데 사용된 광학기기는 분 광측색기(Spectrophotometer, Minolta, CM-2600d, Japan) 이다. 국제조명위원회의 규격에 규정되어 있는 특성과 등 가인 광원을 내장하고 있어 동일한 조건(CIE standard illuminant D65)으로 측정할 수 있으며, 색의 수치화는 물 론 색의 파장 성분을 그래프로 표시할 수 있다. 색의 특성 은 L* a* b* 표색계로 나타내며, 이 방법은 1976년 국제조 명위원회에서 규격화되어 현재 물체의 색을 표현하는 모 든 분야에서 가장 대중적으로 사용되고 있는 표색계 중 하 나이다. 명도를 나타내는 $\mathrm{L}^{*}$ 은 측정범위가 0 에서 100 으로 표시되며 50 을 기준으로 측정값이 높고 낮을수록 흰색 (white)과 검정색(black)에 가까운 것을 의미한다. 채도를 나타내는 $a^{*}, b^{*}$ 는 -60 에서 +60 의 수치로 표시되며, $a *$ 가 (+)일수록 적색(red), (-)일수록 녹색(green)에 가까운 색상 이다. b*는 (+)일수록 황색(yellow), (-)일수록 청색(blue) 에 가까운 색상으로 나타난다. 수치가 클수록 선명한 색이

Table 1. Color difference checklist of National Bureau of Standard Unit, USA.

\begin{tabular}{cc}
\hline$\Delta \mathrm{E}$ value & Evaluation \\
\hline under 0 to 0.5 & trace (색차가 미약) \\
\hline under 0.5 to 1.5 & slight (근소한 정도) \\
\hline under 1.5 to 3.0 & noticeable (눈에 띨 정도) \\
\hline under 3.0 to 6.0 & appreciable (감지할 정도) \\
\hline under 6.0 to 12.0 & much (많다) \\
\hline over 12.0 & very much (매우 많다) \\
\hline
\end{tabular}


Table 2. Color characteristics of $\mathrm{Cu}-10 \% \mathrm{Sn}$ alloys versus microstructures.

\begin{tabular}{|c|c|c|c|c|c|c|}
\hline \multirow{2}{*}{ Sn content } & \multirow{2}{*}{ Chromaticity analysis } & \multicolumn{4}{|c|}{ Chromaticities value(SCE) } & \multirow{2}{*}{ Microstructure } \\
\hline & & $\mathrm{L}^{*}$ & $a^{*}$ & $\mathrm{~b}^{*}$ & $\Delta \mathrm{E}^{*} \mathrm{ab}$ & \\
\hline \multirow{6}{*}{ 10wt.\% } & as-cast & 88.10 & 6.97 & 18.49 & & \multirow{2}{*}{$a+\delta$} \\
\hline & color difference $\mathrm{Cu}-10 \% \mathrm{Sn}$ alloys versus $\mathrm{Cu}$ & 1.47 & -7.06 & 2.25 & 7.55 & \\
\hline & quenching at $550^{\circ} \mathrm{C}$ & 87.44 & 7.43 & 18.31 & & \multirow{2}{*}{$a+\delta$} \\
\hline & color difference versus as-cast & -0.66 & 0.46 & -0.18 & 0.82 & \\
\hline & quenching at $700^{\circ} \mathrm{C}$ & 88.28 & 7.14 & 18.62 & & \multirow{2}{*}{$a+\delta$} \\
\hline & color difference versus as-cast & 0.18 & 0.17 & 0.18 & 0.28 & \\
\hline
\end{tabular}

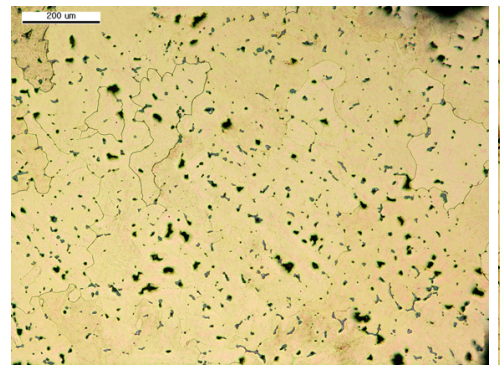

(a) as-cast

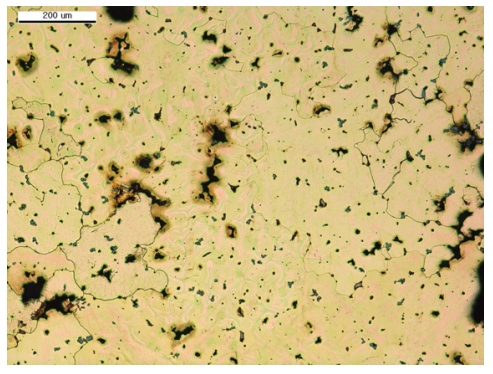

(b) quenching at $550^{\circ} \mathrm{C}$

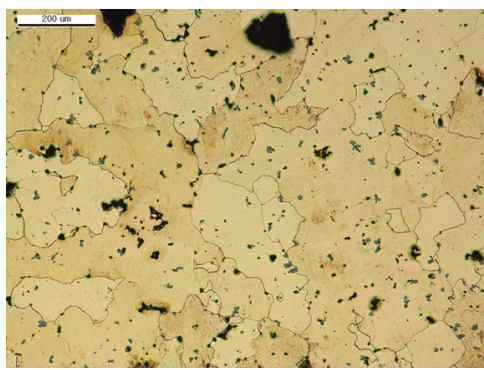

(c) quenching at $700^{\circ} \mathrm{C}$

Figure 1. Changes in microstructure of $\mathrm{Cu}-10 \% \mathrm{Sn}$ alloys by quenching.

되며, 중심이 됨에 따라 모든 색이 섞인 회색톤의 무거운 느낌이 감도는 색으로 나타난다(Koh, 2006). 측정된 $\Delta$ $\mathrm{L}^{*} \mathrm{ab}$ 색차값은 Table 1 의 '미국국가표준원의 색차값 평가 표(National Bureau of Standard Unit)'에 의거하여 색도변 화를 평가하였다. 분광측색기로 측정한 색도의 변화는 $\mathrm{KS}$ $\mathrm{A} 0063$ 의 규정에 의거하여 $\mathrm{L}^{*} \mathrm{a}^{*} \mathrm{~b}^{*}$ 표색계의 색차 $(\Delta \mathrm{E})$ 로 표시하였으며, 색차 $\left(\Delta \mathrm{E}^{*} \mathrm{ab}\right)$ 의 계산방법은 다음과 같 다(Lee et al., 2000).

$$
\Delta \mathrm{E}^{*} \mathrm{ab}=\left[\left(\Delta \mathrm{L}^{*}\right)^{2}+\left(\Delta \mathrm{a}^{*}\right)^{2}+\left(\Delta \mathrm{b}^{*}\right)^{2}\right]^{1 / 2}
$$

색도측정에서 측정광원이 새어나오지 않게 하는 것이 중요하므로 $\mathrm{Cu}-\mathrm{Sn}$ 합금의 표면을 시료연마기에서 편평하 게 연마하였다. 연마한 시편에 남아있는 스크래치는 색도 측정에 영향을 미칠 수 있기 때문에 최종적으로 $1 \mu \mathrm{m}$ diamond suspension을 이용해 표면을 매끄럽게 연마하였다. 연마가 완료된 시편의 표면은 에칭시키지 않은 상태에서 3 회 이상 색도측정하여 평균값을 구했으며, 이때 측정 조건은 표준 광원 $\mathrm{D} 65$, 시야각 $10^{\circ}, \mathrm{UV} 0 \%$, 분석면적 $3 \mathrm{~mm}$ 로 하였다. 또한 SAV방식으로 측정하여 금속 표면의 반사도 값을 제
외하였다.

색도측정이 완료된 시편은 에틸알코올 $120 \mathrm{ml}$, 염산 $30 \mathrm{ml}$, 산화철(III) $10 \mathrm{~g}$ 을 혼합한 용액으로 표면을 에칭시 켰다. 미세조직 관찰은 반사식 광학현미경(DMRBE, Leica, Germany)을 이용하였다.

\section{3. 실험 결과}

\section{1. $\mathrm{Cu}-10 \% \mathrm{Sn}$ 청동}

Table 2는 주석이 $10 \mathrm{wt} . \%$ 포함된 $\mathrm{Cu}-\mathrm{Sn}$ 청동을 $550^{\circ} \mathrm{C}$ 와 $700^{\circ} \mathrm{C}$ 에서 열처리한 뒤, 색도를 각각 비교한 결과이다. $\mathrm{Cu}$ 의 색도와 비교한 $\mathrm{L}^{*} \mathrm{a} * \mathrm{~b} *$ 에서 $\mathrm{a}$ *는 감소하고 $\mathrm{b}$ *는 증 가하여 백색도 보다는 황색도가 증가하였음을 알 수 있다. $\mathrm{Cu}$ 대비 $\Delta \mathrm{E}^{*} \mathrm{ab}$ 색차값은 7.55로 색차가 '많다'로 평가된 다. $550^{\circ} \mathrm{C}$ 와 $700^{\circ} \mathrm{C}$ 에서 열처리한 시편의 $\Delta \mathrm{E}^{*} \mathrm{ab}$ 값이 0.82 이내로 '색차가 미약'하여 색도 변화가 거의 없다. Figure 1 은 as-cast와 $5500^{\circ} \mathrm{C}$ 와 $700^{\circ} \mathrm{C}$ 에서 열처리한 시편 의 미세조직을 보여주는 광학현미경 사진으로 as-cast는 초정 $a$ 상과 $a+\delta$ 의 공석 조직으로 이루어져 있으며, $550^{\circ} \mathrm{C}$ 
Table 3. Color characteristics of $\mathrm{Cu}-15 \% \mathrm{Sn}$ alloys versus microstructures.

\begin{tabular}{|c|c|c|c|c|c|c|}
\hline \multirow{2}{*}{ Sn content } & \multirow{2}{*}{ Chromaticity analysis } & \multicolumn{4}{|c|}{ Chromaticities value(SCE) } & \multirow{2}{*}{ Microstructure } \\
\hline & & $\mathrm{L}^{*}$ & $a^{*}$ & $b^{*}$ & $\Delta \mathrm{E}^{*} \mathrm{ab}$ & \\
\hline \multirow{6}{*}{$15 w t . \%$} & as-cast & 87.91 & 5.15 & 17.53 & & \multirow{2}{*}{$a+\delta$} \\
\hline & color difference $\mathrm{Cu}-15 \% \mathrm{Sn}$ alloys versus $\mathrm{Cu}$ & 1.28 & -8.88 & 1.29 & 9.06 & \\
\hline & quenching at $550^{\circ} \mathrm{C}$ & 88.02 & 5.02 & 17.74 & & \multirow{2}{*}{$a+\delta$} \\
\hline & color difference versus as-cast & 0.11 & -0.13 & -0.21 & 0.27 & \\
\hline & quenching at $700^{\circ} \mathrm{C}$ & 87.97 & 5.08 & 18.56 & & \multirow{2}{*}{$\alpha+\beta(M)$} \\
\hline & color difference versus as-cast & 0.06 & -0.07 & 1.03 & 1.03 & \\
\hline
\end{tabular}

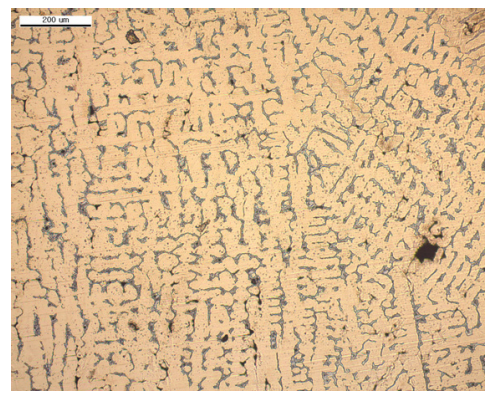

(a) as-cast

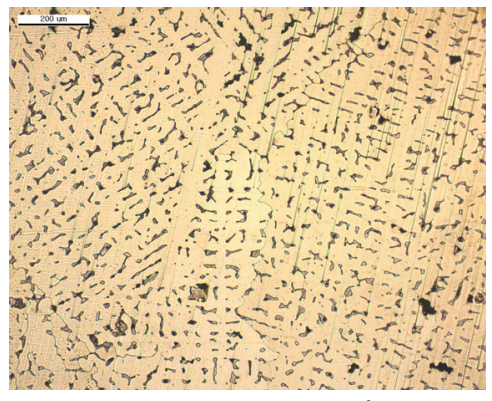

(b) quenching at $550^{\circ} \mathrm{C}$

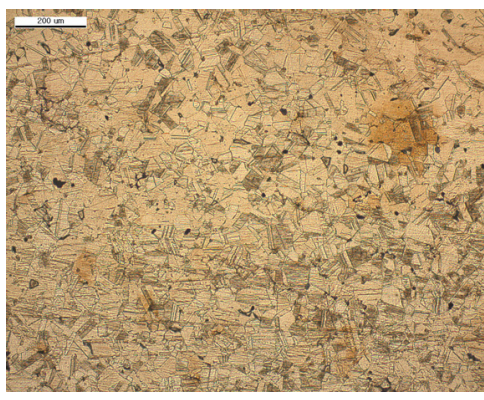

(c) quenching at $700^{\circ} \mathrm{C}$

Figure 2. Changes in microstructure of $\mathrm{Cu}-15 \% \mathrm{Sn}$ alloys by quenching.

와 $700^{\circ} \mathrm{C}$ 에서 열처리한 시편도 수지상의 $\mathrm{a}$ 상과 수지간 영 역에 $a+\delta$ 의 공석 조직이 형성되어 있다. as-cast 시편과 열 처리 시편간의 $\Delta \mathrm{E}^{*} \mathrm{ab}$ 값이 '색차가 미약'으로 평가되는 이유는 미세조직의 변화가 거의 없기 때문으로 판단된다.

\section{2. $\mathrm{Cu}-15 \% \mathrm{Sn}$ 청동}

Table 3은 주석이 $15 w t . \%$ 포함된 $\mathrm{Cu}-\mathrm{Sn}$ 청동을 $550^{\circ} \mathrm{C}$ 와 $700^{\circ} \mathrm{C}$ 에서 열처리한 뒤, 색도를 각각 비교한 결과이다. $\mathrm{Cu}$ 의 색도와 비교한 $\mathrm{L}^{*} \mathrm{a}^{*} \mathrm{~b}$ *에서 $\mathrm{a}^{*}$ 는 감소하고 $\mathrm{b}^{*}$ 는 증 가하여 백색도 보다는 황색도가 증가하였음을 알 수 있다. $\mathrm{Cu}$ 대비 $\Delta \mathrm{E}^{*} \mathrm{ab}$ 색차값은 9.06으로 색차가 '많다'로 평가 된다. 특히 as-cast와 $550^{\circ} \mathrm{C}$ 열처리 시편보다 높아진 $\mathrm{b}^{*}$ 값 은 황색도가 다소 증가하였음을 보여준다. Figure 2는 as-cast와 $550^{\circ} \mathrm{C}, 700^{\circ} \mathrm{C}$ 온도 구간에서 열처리한 시편의 미세조직을 보여주는 광학현미경 사진으로 Figure $2 \mathrm{a}$ 의 as-cast는 초정 $a$ 상과 $a+\delta$ 공석 조직으로 이루어져 있으며, $550{ }^{\circ} \mathrm{C}$ 에서 열처리한 Figure $2 b$ 는 수지상의 $a$ 상과 수지간 영역에 $\delta$ 상이 생성되어 색차도 0.27 로 변화가 거의 없다. 반면 $700^{\circ} \mathrm{C}$ 에서 열처리한 Figure $2 \mathrm{c}$ 는 $a$ 상과 함께 약간의
$\beta(\mathrm{M})$ 상이 생성되었고, 이와 같은 미세조직 변화는 1.03 의 $\Delta \mathrm{E}^{*} \mathrm{ab}$ 값 차이를 보였다. 이와 같은 색도 차이는 '근소한 정도'에 해당한다.

\section{3. $\mathrm{Cu}-22 \% \mathrm{Sn}$ 청동}

Table 4는 주석이 $22 w t . \%$ 포함된 $\mathrm{Cu}-\mathrm{Sn}$ 청동을 $550{ }^{\circ} \mathrm{C}$ 와 $700^{\circ} \mathrm{C}$ 에서 열처리한 뒤, 색도를 각각 비교한 결과이다. $\mathrm{Cu}$ 의 색도와 비교한 $\mathrm{L}^{*} \mathrm{a} * \mathrm{~b}$ *에서 $\mathrm{a}$ *와 $\mathrm{b}^{*}$ 모두 감소하여 백색도가 증가하였으며, $\Delta \mathrm{E}^{*} \mathrm{ab}$ 색차값은 10.09 로 색차가 '많다'로 평가된다. Figure 3 은 as-cast와 $550^{\circ} \mathrm{C}, 700^{\circ} \mathrm{C}$ 의 온도구간에서 열처리한 시편의 미세조직을 보여주는 광학 현미경 사진으로 Figure $3 \mathrm{a}$ 의 as-cast는 초정 $a$ 상과 $a+\delta$ 공 석 조직으로 이루어져 있으며, $550^{\circ} \mathrm{C}$ 에서 열처리한 Figure $3 b$ 는 $a+\gamma$ 상으로 형성되어 있고, $700^{\circ} \mathrm{C}$ 에서 열처리한 Figure $3 c$ 는 $\alpha+\beta(M)$ 상의 미세조직으로 이루어져 있다. 열 처리 조건에 따라 다양한 미세조직이 생성되는 $\mathrm{Cu}-22 \%$ $\mathrm{Sn}$ 합금은 $a$ 상과 $\delta$ 상이 공존할 경우보다 $\gamma$ 상이나 $\beta(\mathrm{M})$ 상 이 $a$ 상과 공존할 때 $b^{*}$ 값이 증가해 황색도가 높아지는 것 으로 분석되었다. 즉 $\mathrm{Cu}$ 에 포함된 $\mathrm{Sn}$ 의 함량과 비례해 함 
Table 4. Color characteristics of $\mathrm{Cu}-22 \% \mathrm{Sn}$ alloys versus microstructures.

\begin{tabular}{|c|c|c|c|c|c|c|}
\hline \multirow{2}{*}{ Sn content } & \multirow{2}{*}{ Chromaticity analysis } & \multicolumn{4}{|c|}{ Chromaticities value(SCE) } & \multirow{2}{*}{ Microstructure } \\
\hline & & $\mathrm{L}^{*}$ & $a^{*}$ & $b^{*}$ & $\Delta \mathrm{E}^{*} \mathrm{ab}$ & \\
\hline \multirow{6}{*}{$22 w t . \%$} & as-cast & 87.04 & 4.21 & 13.93 & & \multirow{2}{*}{$a+\delta$} \\
\hline & color difference $\mathrm{Cu}-22 \% \mathrm{Sn}$ alloys versus $\mathrm{Cu}$ & 0.41 & -9.82 & -2.31 & 10.09 & \\
\hline & quenching at $550^{\circ} \mathrm{C}$ & 86.69 & 5.29 & 15.94 & & \multirow{2}{*}{$a+\gamma$} \\
\hline & color difference versus as-cast & -0.35 & 1.08 & 2.01 & 2.31 & \\
\hline & quenching at $700^{\circ} \mathrm{C}$ & 86.96 & 4.24 & 17.02 & & \multirow{2}{*}{$\alpha+\beta(M)$} \\
\hline & color difference versus as-cast & -0.08 & 0.03 & 3.09 & 3.09 & \\
\hline
\end{tabular}

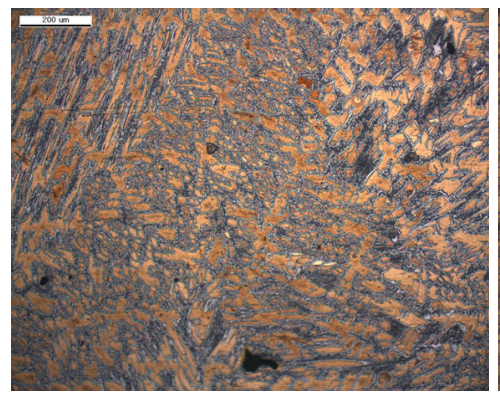

(a) as-cast

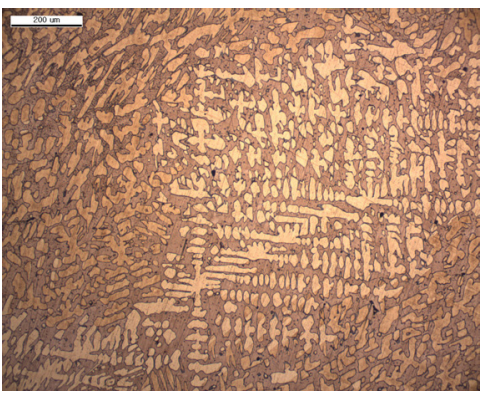

(b) quenching at $550^{\circ} \mathrm{C}$

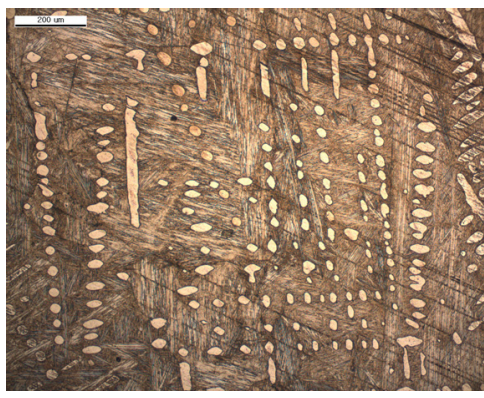

(c) quenching at $700^{\circ} \mathrm{C}$

Figure 3. Changes in microstructure of $\mathrm{Cu}-22 \% \mathrm{Sn}$ alloys by quenching.

량비율이 높은 $\delta$ 상의 백색도는 높은 반면 $\delta$ 상보다 함량비 율이 낮은 $\gamma, \beta$ 상의 백색도는 낮아지고 황색도는 높아졌 다. $550^{\circ} \mathrm{C}$ 에서 열처리한 시편의 as-cast 대비 $\Delta \mathrm{E}^{*} \mathrm{ab}$ 값은 2.31 로 '눈에 띨 정도'로 평가되며, $700^{\circ} \mathrm{C}$ 에서 열처리한 시편의 $\Delta \mathrm{E}^{*} \mathrm{ab}$ 값도 3.09 로 '감지할 정도'로 평가된다.

\section{4. $\mathrm{Cu}-25 \% \mathrm{Sn}$ 청동}

Table 5 는 주석이 $25 \mathrm{wt} . \%$ 포함된 $\mathrm{Cu}-\mathrm{Sn}$ 청동을 $550^{\circ} \mathrm{C}$ 와 $700^{\circ} \mathrm{C}$ 에서 열처리한 뒤, 색도를 각각 비교한 표이다. $\mathrm{Cu}$ 의 색도와 비교한 $\mathrm{L}^{*} \mathrm{a}^{*} \mathrm{~b}$ *에서 $\mathrm{a}$ *와 $\mathrm{b}^{*}$ 모두 감소하여 백색도가 증가하였으며, $\Delta \mathrm{E}^{*} \mathrm{ab}$ 색차값은 13.82 로 색차가 '매우 많다'로 평가된다. Figure 4는 as-cast와 $550^{\circ} \mathrm{C}, 70$ $0^{\circ} \mathrm{C}$ 의 온도구간에서 열처리한 시편의 미세조직을 보여주 는 광학현미경 사진으로 Figure $4 \mathrm{a}$ 의 as-cast는 초정 $\alpha$ 상과 $a+\delta$ 공석 조직으로 이루어져 있으며, $550^{\circ} \mathrm{C}$ 에서 열처리한 Figure $4 b$ 는 $a+\gamma$ 상으로 형성되어 있고, $700^{\circ} \mathrm{C}$ 에서 열처리 한 Figure $4 \mathrm{c}$ 는 $\beta(\mathrm{M})$ 상의 미세조직으로 이루어져 있다. 열 처리 조건에 따라 다양한 미세조직이 생성되는 $\mathrm{Cu}-25 \%$ $\mathrm{Sn}$ 합금은 $\alpha+\delta$ 상으로 된 as-cast 보다 $a+\gamma$ 상의 $550^{\circ} \mathrm{C}$ 열
처리 시편에서 적색도와 황색도가 증가하였으며, $\beta(\mathrm{M})$ 상 만 형성시킨 $700^{\circ} \mathrm{C}$ 열처리 시편에서도 적·황색도가 증가하 였다. 이와 같은 현상은 고온에서의 열처리 작업을 통해 as-cast에 있던 $\delta$ 상을 제거시킨 결과로 보인다. 한편 $\beta(\mathrm{M})$ 단일상으로 이루어진 $700^{\circ} \mathrm{C}$ 열처리 시편보다 $a+\gamma$ 상의 $550^{\circ} \mathrm{C}$ 열처리 시편에서 적색도가 조금 높게 측정되었는 데, 이는 구리 함량이 높은 $\mathrm{a}$ 상이 공존하며 $\mathrm{a}$ *값을 상승시 켰고, 이 $a$ 상이 적색도 증가에 영향을 미친 것으로 보인다. $550^{\circ} \mathrm{C}$ 에서 열처리한 시편의 as-cast 대비 $\triangle \mathrm{E}^{*} \mathrm{ab}$ 값은 4.54 로 '감지할 정도'로 평가되며, $700^{\circ} \mathrm{C}$ 에서 열처리한 시 편의 $\Delta \mathrm{E}^{*} \mathrm{ab}$ 값도 5.38 로 '감지할 정도'로 평가된다.

\section{5. $\mathrm{Cu}-27 \% \mathrm{Sn}$ 청동}

Table 6 은 주석이 $27 \mathrm{wt} . \%$ 포함된 $\mathrm{Cu}-\mathrm{Sn}$ 청동을 $550^{\circ} \mathrm{C}$ 와 $700^{\circ} \mathrm{C}$ 에서 열처리한 뒤, 색도를 각각 비교한 표이다. 구 리의 색도와 비교한 $\mathrm{L}^{*} \mathrm{a}^{*} \mathrm{~b}$ *에서 $\mathrm{a}$ *와 $\mathrm{b}$ * 모두 감소하여 백색도가 증가하였으며, $\Delta \mathrm{E}^{*} \mathrm{ab}$ 색차값은 15.16 으로 색차 가 '매우 많다'로 평가된다. Figure 5 는 as-cast와 $550^{\circ} \mathrm{C}$, $700^{\circ} \mathrm{C}$ 의 온도구간에서 열처리한 시편의 미세조직을 보여 
Table 5. Color characteristics of $\mathrm{Cu}-25 \% \mathrm{Sn}$ alloys versus microstructures.

\begin{tabular}{|c|c|c|c|c|c|c|}
\hline \multirow{2}{*}{ Sn content } & \multirow{2}{*}{ Chromaticity analysis } & \multicolumn{4}{|c|}{ Chromaticities value(SCE) } & \multirow{2}{*}{ Microstructure } \\
\hline & & $\mathrm{L}^{*}$ & $a^{*}$ & $b^{*}$ & $\Delta \mathrm{E}^{*} \mathrm{ab}$ & \\
\hline \multirow{6}{*}{$25 w t . \%$} & as-cast & 86.15 & 2.58 & 8.52 & & \multirow{2}{*}{$a+\delta$} \\
\hline & color difference $\mathrm{Cu}-25 \% \mathrm{Sn}$ alloys versus $\mathrm{Cu}$ & -0.48 & -11.45 & -7.72 & 13.82 & \\
\hline & quenching at $550^{\circ} \mathrm{C}$ & 84.85 & 5.02 & 12.12 & & \multirow{2}{*}{$a+\gamma$} \\
\hline & color difference versus as-cast & -1.30 & 2.44 & 3.60 & 4.54 & \\
\hline & quenching at $700^{\circ} \mathrm{C}$ & 85.33 & 4.43 & 13.51 & & \multirow{2}{*}{$\beta(\mathrm{M})$} \\
\hline & color difference versus as-cast & -0.82 & 1.85 & 4.99 & 5.38 & \\
\hline
\end{tabular}

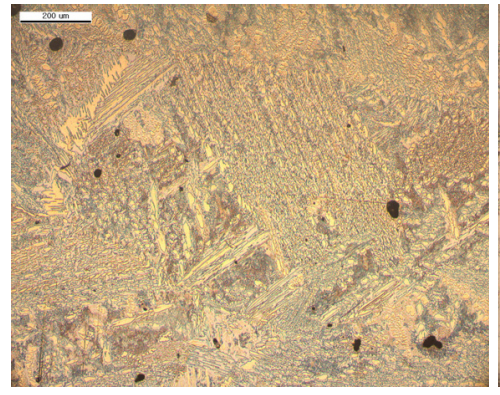

(a) as-cast

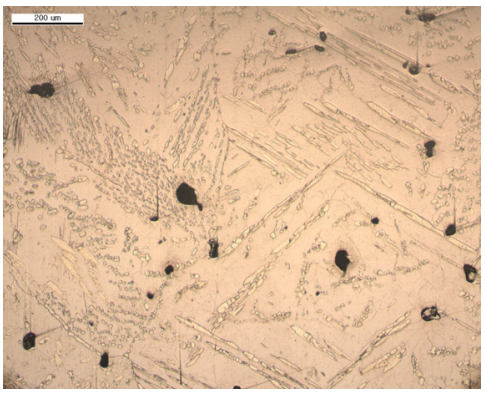

(b) quenching at $550^{\circ} \mathrm{C}$

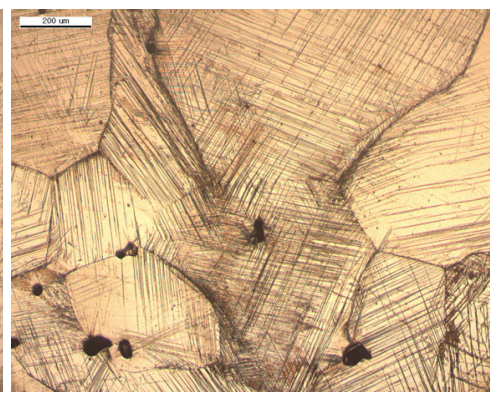

(c) quenching at $700^{\circ} \mathrm{C}$

Figure 4. Changes in microstructure of $\mathrm{Cu}-25 \% \mathrm{Sn}$ alloys by quenching.

주는 광학현미경 사진으로 Figure $6 \mathrm{a}$ 의 as-cast는 $a+\delta$ 상으 로 이루어져 있으며, $550^{\circ} \mathrm{C}$ 에서 열처리한 Figure $5 \mathrm{~b}$ 는 $\gamma$ 상 으로 형성되어 있고, $700^{\circ} \mathrm{C}$ 에서 열처리한 Figure $5 \mathrm{c}$ 도 $\gamma$ 상 의 미세조직으로 이루어져 있다. $\mathrm{Cu}-27 \% \mathrm{Sn}$ 합금은 $a+\delta$ 상으로 형성된 as-cast 보다 $\gamma$ 상만 형성된 $550^{\circ} \mathrm{C}$ 와 $700^{\circ} \mathrm{C}$ 열처리 시편에서 적색도와 황색도를 나타내는 $a^{*}, b^{*}$ 값이 증가하였다. $550^{\circ} \mathrm{C}$ 와 $700^{\circ} \mathrm{C}$ 에서 열처리한 시편과 as-cast 의 색도를 상호 비교하면 4.65 이상의 $\triangle \mathrm{E}^{*} \mathrm{ab}$ 값이 나타나 며, 이와 같은 수치는 미국국가표준원의 색차값 평가표에 서 ‘감지할 정도'로 평가된다. 한편 $550^{\circ} \mathrm{C}$ 와 $700^{\circ} \mathrm{C}$ 의 열처 리 조건에 의해 $\gamma$ 상만 형성된 시편의 색차에는 거의 차이 가 없는 것으로 분석되었는데, 이는 열처리조건이 다르더 라도 미세조직의 변화가 생기지 않으면 색차에도 변화가 없음을 의미한다.

\section{6. $\mathrm{Cu}-30 \% \mathrm{Sn}$ 청동}

Table 7은 주석이 $30 w t . \%$ 포함된 $\mathrm{Cu}-\mathrm{Sn}$ 청동을 $550{ }^{\circ} \mathrm{C}$ 와 $700^{\circ} \mathrm{C}$ 에서 열처리한 뒤, 색도를 각각 비교한 결과이다. 구리의 색도와 비교한 $\mathrm{L}^{*} \mathrm{a}^{*} \mathrm{~b}$ *에서 $\mathrm{a}^{*}$ 와 $\mathrm{b}^{*}$ 모두 크게 감
소하여 백색도가 증가하였으며, $\Delta \mathrm{E}^{*} \mathrm{ab}$ 색차값은 16.10 으 로 색차가 '매우 많다'로 평가된다. Figure 6은 as-cast와 $550^{\circ} \mathrm{C}, 700^{\circ} \mathrm{C}$ 의 온도구간에서 열처리한 시편의 미세조직 을 보여주는 광학현미경 사진으로 Figure $6 \mathrm{a}$ 의 as-cast는 $\delta$ 상을 바탕으로 적은 양의 $a+\delta$ 공석상이 자리잡고 있다. $550^{\circ} \mathrm{C}$ 에서 열처리한 Figure $6 \mathrm{~b}$ 는 $\gamma+\delta$ 상으로 이루어져 있 고, $700^{\circ} \mathrm{C}$ 에서 열처리한 Figure $6 \mathrm{c}$ 는 $\gamma$ 상의 미세조직으로 형성 되었다. 열처리 조건에 따라 다양한 미세조직이 생성 되는 $\mathrm{Cu}-30 \% \mathrm{Sn}$ 합금은 $\mathrm{a}+\delta$ 상으로 된 as-cast 보다 $\gamma+\delta$ 상의 $550^{\circ} \mathrm{C}$ 열처리 시편에서 적색도와 황색도가 조금 증 가하였으며, $\gamma$ 상만 형성시킨 $700^{\circ} \mathrm{C}$ 열처리 시편에서도 적. 황색도가 조금 증가하였다. 하지만 as-cast와 열처리 시편 의 $a^{*}, b^{*}$ 색차값은 $0.3 \sim 1.7$ 이내로 색도 변화가 매우 미미 하다. $550^{\circ} \mathrm{C}$ 에서 열처리한 시편의 as-cast 대비 $\Delta \mathrm{E}^{*} \mathrm{ab}$ 값 은 1.25 로 '근소한 정도'로 평가되며, $700^{\circ} \mathrm{C}$ 에서 열처리한 시편의 $\Delta \mathrm{E}^{*} \mathrm{ab}$ 값도 1.81 로 '눈에 띨 정도'로 평가된다. $\mathrm{Sn}$ 함량이 높은 $\mathrm{Cu}-30 \% \mathrm{Sn}$ 합금은 고온에서의 열처리 작업 을 통해 미세조직에 변화를 주어도 색도에는 그 변화가 적 게 나타났다. 
Table 6. Color characteristics of $\mathrm{Cu}-27 \% \mathrm{Sn}$ alloys versus microstructures.

\begin{tabular}{|c|c|c|c|c|c|c|}
\hline \multirow{2}{*}{ Sn content } & \multirow{2}{*}{ Chromaticity analysis } & \multicolumn{4}{|c|}{ Chromaticities value(SCE) } & \multirow{2}{*}{ Microstructure } \\
\hline & & $\mathrm{L}^{*}$ & $a^{*}$ & $b^{*}$ & $\Delta \mathrm{E}^{*} \mathrm{ab}$ & \\
\hline \multirow{6}{*}{$27 \mathrm{wt} . \%$} & as-cast & 85.56 & 2.29 & 6.71 & & \multirow{2}{*}{$a+\delta$} \\
\hline & color difference $\mathrm{Cu}-27 \% \mathrm{Sn}$ alloys versus $\mathrm{Cu}$ & -1.07 & -11.74 & -9.53 & 15.16 & \\
\hline & quenching at $550^{\circ} \mathrm{C}$ & 83.90 & 4.19 & 10.83 & & \multirow{2}{*}{$\gamma$} \\
\hline & color difference versus as-cast & -1.66 & 1.90 & 4.12 & 4.83 & \\
\hline & quenching at $700^{\circ} \mathrm{C}$ & 84.44 & 4.68 & 10.54 & & \multirow{2}{*}{$\gamma$} \\
\hline & color difference versus as-cast & -1.12 & 2.39 & 3.83 & 4.65 & \\
\hline
\end{tabular}

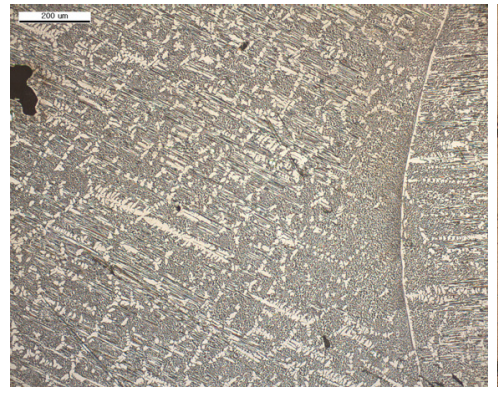

(a) as-cast

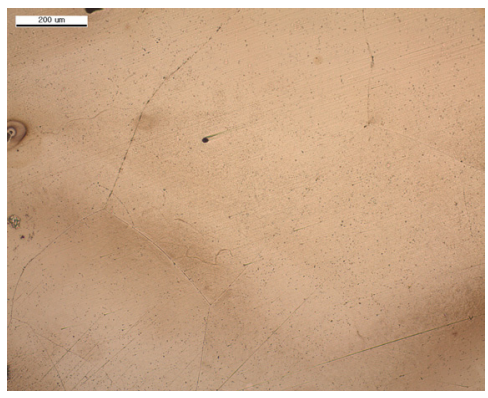

(b) quenching at $550^{\circ} \mathrm{C}$

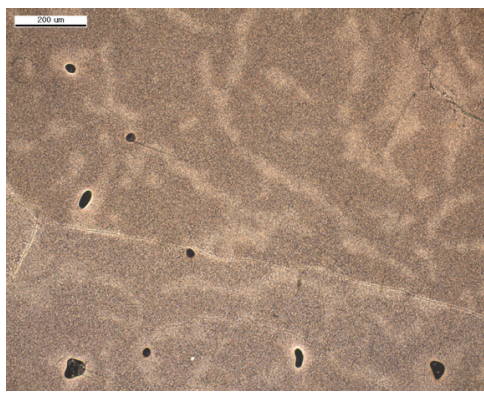

(c) quenching at $700^{\circ} \mathrm{C}$

Figure 5. Changes in microstructure of $\mathrm{Cu}-27 \% \mathrm{Sn}$ alloys by quenching.

\section{4. 고 찰}

청동은 주석 함유량에 따라 기계적 성질과 색상이 변하 게 된다. 구리의 색상은 붉고 주석의 색상은 희다. 주석의 비율이 높아지면 색상이 점차 황색에서 담황색, 백색으로 변화된다(Hirao, Y., 2001). 따라서 청동기는 사용목적에 따라 나타나는 색상도 중요했을 것이다. 청동거울의 경우 노란색보다는 은백색의 윤이 나는 거울을 선호했을 것이 고 동탁은 노란 금색을 더 좋아했을 것이다. 이렇게 청동기 의 색상은 청동기 연구의 중요한 요소가 된다. 즉 청동기의 성분조성을 정확히 이해하는 것은 청동기의 용해온도, 경 도, 색상에 관한 당시의 기술수준을 이해하는데 중요한 조 건이다(Cho, 2009). 청동기의 색도에 관한 연구는 주석의 함량에 따라 색상이 변하는 사실들을 바탕으로 W.T.Chase 가 시료를 통한 직접적인 색상연구로 그 연관성을 더하였 으며, Johnson-Feller n.d.의 그래프에 $\mathrm{Cu}-\mathrm{Sn}$ 합금 비율에 따른 시료들을 Munsell hues의 값들로 대입시켜 청동 합금 의 색상이 주석 함량과 직접적인 관련을 보인다는 것을 확 인하였다(Huh, 2006).

적색의 금속인 구리는 색도 분석 결과에서 다른 금속보
다 매우 높은 적색도를 나타냈다. 여기에 주석을 $10 \%$ 포함 시킨 청동합금과 구리와의 색차값( $\left.\Delta \mathrm{E}^{*} \mathrm{ab}\right)$ 은 7.55 로 나타 나는데, 이는 미국국가표준원에서 제시하는 색차값 평가 표의 기준을 적용시킬 경우 '많다'로 평가되며, 이와 같은 색차값은 $\mathrm{Sn}$ 의 비율이 높아질수록 꾸준히 늘어 $\mathrm{Sn} 30 \%$ 에 서는 $\operatorname{Sn~} 10 \%$ 의 약 2 배인 16.10 의 $\Delta \mathrm{E}^{*} \mathrm{ab}$ 값에 이른다. 이 는 순구리에 주석비율이 높아질수록 $\mathrm{a} *$ 와 $\mathrm{b}$ *값은 낮아지 는 현상에 의한 것으로 합금 내에 주석이 추가됨에 따라 백 색도는 높아지고, 적황색은 옅어지는 것으로 해석된다. 하 지만 백색도와 밀접한 $\mathrm{L}^{*}$ 값은 오히려 감소하는 매우 특이 한 현상을 보여 이 부분에 대한 추가 연구가 필요하다.

$\mathrm{Cu}-\mathrm{Sn}$ 청동기의 열처리 여부에 따른 색도변화를 나타 낸 Figure 7을 보면 미세조직의 변화가 크지 않은 $\mathrm{Sn}$ 의 함 량 $15 \%$ 이하에서는 색차값 $\left(\Delta \mathrm{E}^{*} \mathrm{ab}\right)$ 의 차이도 거의 없다. 하지만 미세조직의 변화가 크게 나타나기 시작하는 $\mathrm{Sn}$ 함 량 $22 \%$ 이상에서는 색차값의 차이가 큰 것을 볼 수 있다. 특히 $550^{\circ} \mathrm{C}$ 와 $700^{\circ} \mathrm{C}$ 에서 담금질한 시편보다 as-cast 시편 에서 색차값이 크게 나타났다. 이는 고온에서 담금질한 시 편에서는 색상이 유사한 $\beta$ 상과 $\gamma$ 상이 생성된 반면 as-cast 시편은 백색도가 높은 $\delta$ 상이 포함되어 있기 때문으로 판단 
Table 7. Color characteristics of $\mathrm{Cu}-30 \% \mathrm{Sn}$ alloys versus microstructures.

\begin{tabular}{|c|c|c|c|c|c|c|}
\hline \multirow{2}{*}{ Sn content } & \multirow{2}{*}{ Chromaticity analysis } & \multicolumn{4}{|c|}{ Chromaticities value(SCE) } & \multirow{2}{*}{ Microstructure } \\
\hline & & $\mathrm{L}^{*}$ & $a^{*}$ & $b^{*}$ & $\Delta \mathrm{E}^{*} \mathrm{ab}$ & \\
\hline \multirow{6}{*}{ 30wt.\% } & as-cast & 85.41 & 1.75 & 5.90 & & \multirow{2}{*}{$a+\delta$} \\
\hline & color difference $\mathrm{Cu}-30 \% \mathrm{Sn}$ alloys versus $\mathrm{Cu}$ & -1.22 & -12.28 & -10.34 & 16.10 & \\
\hline & quenching at $550^{\circ} \mathrm{C}$ & 85.18 & 2.08 & 7.09 & & \multirow{2}{*}{$\gamma+\delta$} \\
\hline & color difference versus as-cast & -0.23 & 0.30 & 1.19 & 1.25 & \\
\hline & quenching at $700^{\circ} \mathrm{C}$ & 85.14 & 2.31 & 7.60 & & \multirow{2}{*}{$\gamma$} \\
\hline & color difference versus as-cast & -0.27 & 0.56 & 1.70 & 1.81 & \\
\hline
\end{tabular}

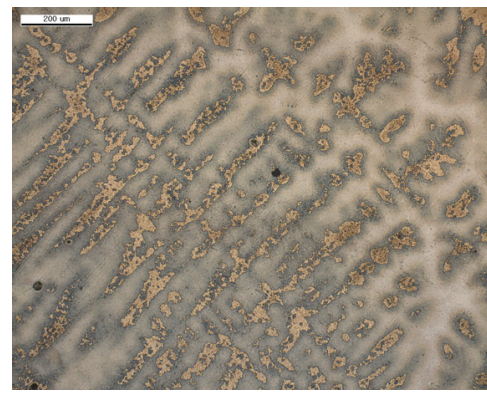

(a) as-cast

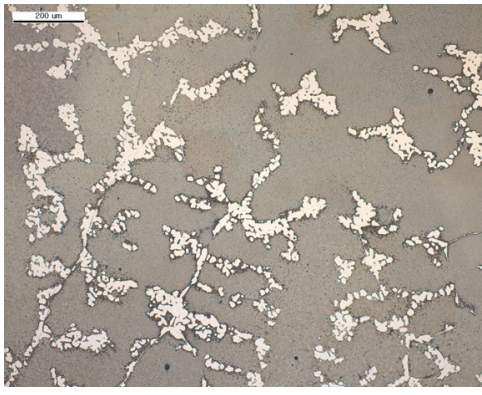

(b) quenching at $550^{\circ} \mathrm{C}$

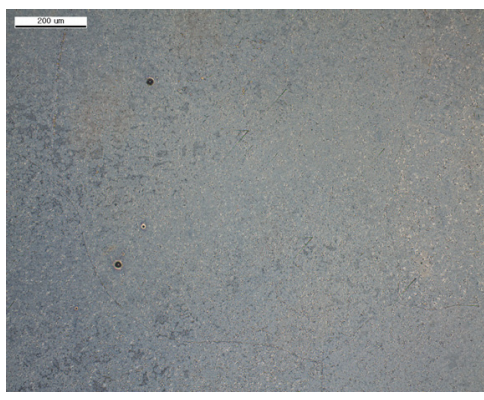

(c) quenching at $700^{\circ} \mathrm{C}$

Figure 6. Changes in microstructure of $\mathrm{Cu}-30 \% \mathrm{Sn}$ alloys by quenching.

된다. 또한 주석함량이 높아질수록 백색도를 나타내는 $\mathrm{L}^{*}$ 값은 증가하고, 적·황색도를 나타내는 $\mathrm{a}$ *와 $\mathrm{b}$ *값은 감소하 였다. $\mathrm{Cu}-\mathrm{Sn}$ 청동기의 색도를 미세조직과 관계지어 살펴 보면 $\mathrm{a}$ 상의 비율이 증가할수록 $\mathrm{a}^{*}$ 와 $\mathrm{b}^{*}$ 값이 높아졌고, 이 는 적 · 황색도가 높아지는 결과로 이어졌다. 한편 $\delta$ 상의 비 율이 증가할수록 $\mathrm{a}$ *와 $\mathrm{b}$ *값이 낮아 졌고, 이는 적·황색도가 낮아지는 결과로 나타났다. 특히 동일한 성분 조성을 가진 $\mathrm{Cu}-22 \% \mathrm{Sn}$ 합금을 다양한 열처리 조건으로 상변화를 일 으킬 경우 주조 조직인 $a+\delta$ 상과 담금질 조직인 $a+\gamma$ 상, $a+$ $\beta(\mathrm{M})$ 상에서 미세한 색변화가 나타났다. 이는 동일한 조성 의 합금도 다른 함량을 가진 미세조직을 생성시킴에 따라 색상 변화가 생길 수 있음을 보여준다. 다양한 청동기의 열 처리를 통해 미세조직의 색상을 확인하였다. 따라서 청동 기를 이루는 미세조직의 고유한 색상과 이에 따른 색상의 변화는 매우 중요한 것으로 판단된다.

\section{5. 결 론}

주석함량을 무게비 10 에서 $30 \%$ 까지 포함한 $\mathrm{Cu}-\mathrm{Sn}$ 청 동기의 색도를 미세조직 변화와 함께 분석한 결과 다음과

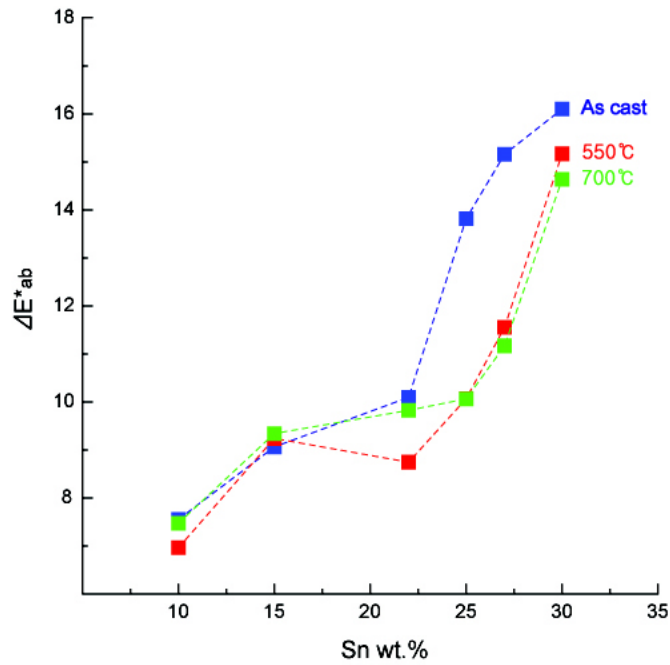

Figure 7. Changes in chromaticities of $\mathrm{Cu}-\mathrm{Sn}$ alloys by quenching.

같은 사실을 확인하였다.

1. $\mathrm{Cu}-\mathrm{Sn}$ 청동기는 주석함량이 높아질수록 적·황색도 를 나타내는 $a^{*}$ 와 $b$ *값은 감소하며, 전체적인 백색도가 크 
게 증가하였다. 하지만 백색도와 밀접한 $\mathrm{L}^{*}$ 값이 감소하는 특이한 현상을 보였다.

2. $\mathrm{Cu}-\mathrm{Sn}$ 청동기의 미세조직 내에서 존재하는 $\mathrm{a}$ 상의 비 율이 증가될수록 $\mathrm{a} *$ 와 $\mathrm{b}$ *값이 높아졌고, 이는 적·황색도 가 높아지는 결과로 이어졌다. 한편 $\delta$ 상의 비율이 증가할 수록 $\mathrm{a} *$ 와 $\mathrm{b} *$ 값이 낮아졌고, 이는 적·황색도가 낮아지는 결 과로 나타났다. 즉 주석함량이 가장 낮은 $a$ 상의 색상이 적 황색이며, 주석함량과 백색도가 높은 $\delta$ 상이 증가할수록 청 동기의 색상이 백색으로 변화한다는 것을 알 수 있다.

3. 담금질 조건에 따라 미세조직의 다양한 변화를 보이 는 $\mathrm{Cu}-22 \% \mathrm{Sn}$ 청동기를 다양한 열처리 조건에서 상변화 를 일으킬 경우 주조 조직인 $a+\delta$ 상과 담금질 조직인 $a+\gamma$ 상, $\alpha+\beta(\mathrm{M})$ 상에서 미세한 색변화가 나타났다. 이는 동일 한 조성의 합금도 다른 함량을 가진 미세조직을 생성시킴 에 따라 색상의 변화가 생길 수 있음을 보여준다.

4. $\mathrm{Cu}-\mathrm{Sn}$ 청동기를 담금질할 경우, 합금 내에서의 미세 조직 변화에 따른 적·황색도는 $\alpha, \beta, \gamma, \delta$ 상 순으로 감소하 였다.

\section{사 사}

이 논문은 2014년도 정부(교육부)의 재원으로 한국연구 재단의 지원을 받아 수행되었다(2013R1A1A2059128).

\section{REFERENCES}

Cho, N.C and Kim, G.H, 2009, Material properties of high-tin bronzes in Korea, International Scientific Meeting in Korea "Production technology of high-tin bronzes in Korea", Foundation of East-Asia culture properties institute, 19-20. (in Korean with English abstract)

Chung, K.Y., Yun, Y.H., and Lee, H.S., 2008, Restoration and
Production technology of Cultural properties, Seogyeong Publishing Co. 275. (in Korean)

Gyeonggi provincial museum, 2008, Analytical report of the Gwangju royal kilns complex at Gwangju in Gyeonggi province.

Huh, I.K., 2006, Metallurgical study of bronze mirror and bells excavated from the Miruksa temple site, thesis, Hanseo University, Seosan, 14-15. (in Korean with English abstract)

Hirao. Y., 1999, BUNKAZAI WO SAGURU KAGAKU NO ME, Hakyounmunhwasa Publishing Co., 36-39. (in Japanese)

Jo, J.S., Kim, J.H., Noh, H.S., Kim, S.M., Je, J.W., and Choi. J.H., 2014, The casting and using experiment of rectangular shaped bronze axe, J. of Korean Field Archaeology, No. 20. 5-38. (in Korean with English abstract)

Kang, H.T., Cho, N.C., and Huh, I.K., 2006, Metallurgical Characteristics and conservation of Ancien bronze object Gilguem Institute of craft art. (in Korean)

Koh, M.J., 2006, The Analysis of Physical Characteristics and Raw Materials on Hard and Soft Whiteware at Excavated Kilns in Gyeongsangnam-do, Korea, Kongju National University, Gongju. (in Korean)

Lee, H.Y., Chung, Y.J., Lee, K.S., and Han, S.H., 2000, The investigation of conservation methods and destruction regions of papers under the various temperature and humidity changes, Consevation Studies, Vol. 34, National Research Institute of Cultural Heritage. 146-175. (in Korean with English abstract)

W.T. Chase., 1991, Ancient and historic metal, The Getty Conservation Institute, 94-97. 